\title{
Cladonia lichens as the most effective and essential pioneers in strongly contaminated slag dumps
}

Piotr Osyczka ${ }^{1, *}$, Kaja Rola ${ }^{2}$

'Department of Polar Research and Documentation, Institute of Botany, Jagiellonian University, 31-501 Kraków, Poland

${ }^{2}$ Department of Plant Taxonomy, Phytogeography and Herbarium, Institute of Botany, Jagiellonian University, 31-501 Kraków, Poland

Received 18 December 2012; Accepted 16 May 2013

\begin{abstract}
The epigeic lichen biota of ten post-smelting slag dumps were studied to identify the ecological importance of Cladonia species in spontaneous succession within artificial areas. Species diversity, abundance, constancy and cover indices were determined at the initial stages of vegetation establishment. Substrates under lichen vegetation were characterised in terms of the $\mathrm{pH}$, organic $\mathrm{C}$ and total $\mathrm{N}$ content, $\mathrm{C} / \mathrm{N}$ ratio and $\mathrm{Zn}, \mathrm{Pb}, \mathrm{Cd}$ and $\mathrm{As}$ concentration. Species occurrence and abundance indices were related to habitat type, enabling the ability to identify species-specific responses to environmental factors. Despite the unfavourable and artificial habitat conditions at dump sites, some Cladonia appear abundant and form swards, with Cladonia rei as a dominant species. They appear to be well-adapted for slag substrate and their special arrangement illustrative of site contamination. Certain sward-forming Cladonia lichens play a fundamental role as effective pioneers in the initial stage of succession and provide stable plant cover development.
\end{abstract}

Keywords: Slag waste • Metal contamination • Lichen succession • Metal resistance • Industrial area

(C) Versita Sp. z 0.0

\section{Introduction}

Mining and heavy industry have substantially transformed the landscape and contaminated the environment. Large quantities of wastes have been deposited in post-industrial areas as dumps, and the amount of land base taken up by these artificial deposits is extensive. The dumps associated with the extraction of zinc and lead ores have different physical and chemical properties, which are the result of different processing methods. They can be generally divided into three types [1,2]: (1) post-mining dumps - a mixture of dolomites, limestone, clays, sands and gravels; (2) postflotation dumps - a flotation sludge mixed with finely ground dolomite and (3) post-smelting dumps - slag from blast and muffle furnaces consisting of crumbs of dolomite, sinter slag, coke residue, $\mathrm{Pb}$-rich and $\mathrm{Zn}$-rich wastes. The latter dumps constitute completely artificial environment ecosystems characterised by extremely high concentrations of toxic elements [3] and the most unfavourable habitat conditions [4].

Due to the necessity of reducing the negative impacts on the local environment and indigenous populations and the need for reclamation interventions, postindustrial areas have become interesting opportunities for biological and ecological investigations (e.g. [5-7]). Some lichens are known as effective and rapid colonisers of bare ground and their pioneer nature is not only associated with a primary succession of natural sites, but also concerns anthropogenic and artificial habitats (e.g. $[8,9])$. Anthropogenic disturbances frequently contribute to the formation of lichen dominated communities (e.g. [10]), and many species are important colonisers of degraded soil [11]. Since different lichen taxa display different levels of sensitivity to heavy metals, the presence of particular elements in the environment may produce changes at the community level [12]. Lichens from various genera, including Cladonia, are known to 
tolerate heavy metal contamination and grow in both polluted and unpolluted areas (see $[13,14])$. There are also examples of lichens that appear to be limited to heavy metal-rich substrates, and thus, these lichens are often used as good indicators of the presence of certain metal elements in the substrate (see [14]). Moreover, several new species have been recognised and described from areas enriched with metals, such as Cd, Cu and Zn [15-17].

The data on the lichen biota existing in extremely contaminated sites and especially the knowledge about the response of particular species to highly unfavourable habitat conditions are very limited [e.g. 18-23]. Despite adverse factors, there are lichens that effectively colonise such areas, and interestingly, some of them are abundant and form compact swards. This study focuses on epigeic lichens, primarily those of Cladonia species, as they constitute the largest proportion of biomass in the early stages of succession at man-made dump sites. Specifically, the research (1) determines the diversity of lichen species and their abundance and (2) estimates the relationships between the abundances of particular species and specific habitat factors.

\section{Experimental Procedures}

\subsection{Studied post-smelting dumps}

The study concerns areas directly associated with the processing of lead and zinc ores in the central part of the Upper Silesian Industrial Region, S Poland (Figure 1). The primitive metal smelting technology of the past has resulted in large quantities of wastes, which were deposited in post-industrial areas as dumps. The locations and size of the dumps are provided in Table 1. The matter of dumps primarily constituted post-smelting slag, which has weathered over time into a form of friable substrate or partially moulding sinters. Despite the fact that generally the main deposition of slag wastes was finished, the dumps are still partially exploited and notoriously affected by human activities (e.g. extraction of material for roads construction, crushing by heavy vehicles, trampling, searching for scrap-iron by local residents). The extent of the area, an extreme degree of contamination and difficulties in reclamation cause the dumps a large and still unsolved environmental problem in the Silesian region [24].

\subsection{Field studies and sampling}

The dumps were studied in 2010 and 2011 during a dry spring seasons. Lichens overgrowing friable slag substrate were examined and as the examples of typical apophytes (see $[25,26]$ ) they were treated as epigeic species. At each dump, three study plots of $100 \times 100 \mathrm{~cm}$ representing the initial stage of succession were randomly selected to determine the abundance of lichen species. The following cover-abundance scale was used (modified after [27]): $r$ : $<5 \%$ cover and 1-5 individuals; $1:<5 \%$ cover and several individuals; 2a: cover 5-12.5\%; 2b: cover 12.5-25\%; 3: cover

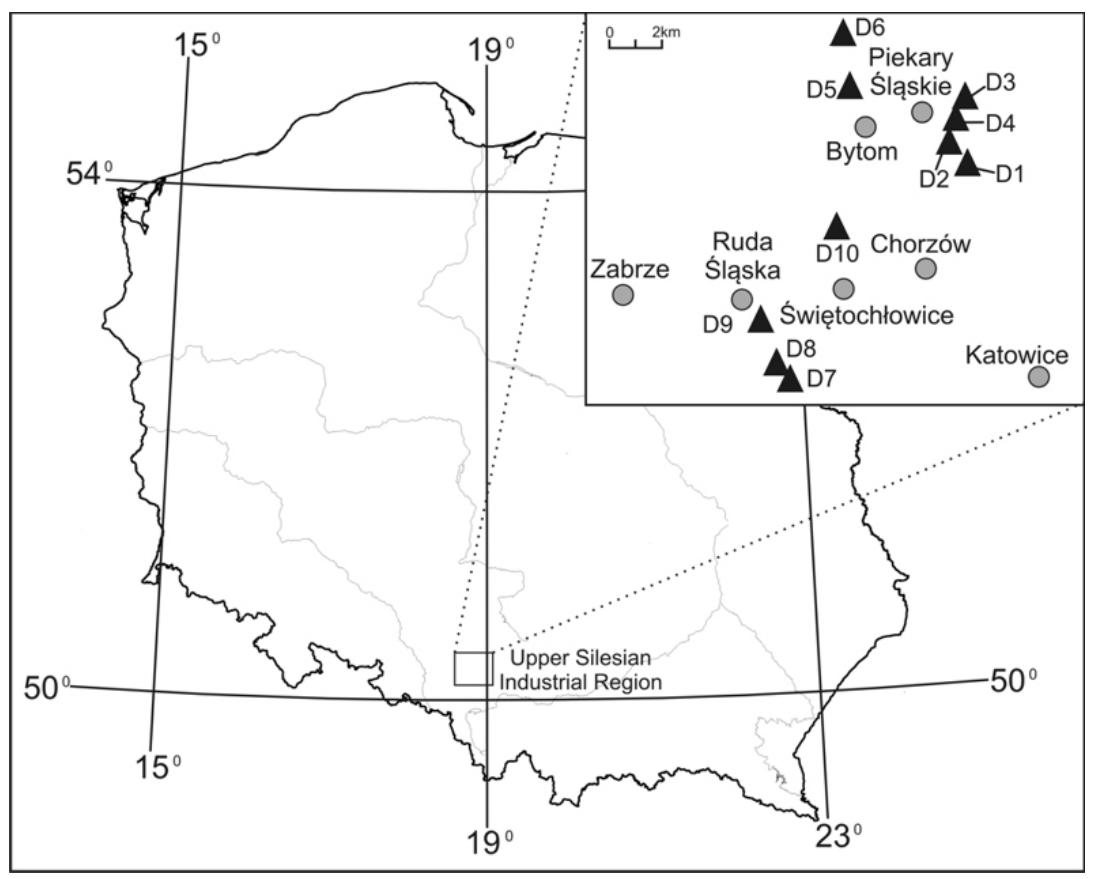

Figure 1. Locations of study dumps in the Upper Silesian Industrial Region ( $\Delta$ D1-D10 - dumps, see Table 1; $\bullet$ main towns in the study area). 


\begin{tabular}{c|ccc}
\hline Dump & Locality (town) & Coordinates (centre of the dump) & Approx. area $\left(\mathrm{m}^{2}\right)$ \\
\hline \hline D1 & Piekary Śląskie & $50^{\circ} 20^{\prime} 34^{\prime \prime} \mathrm{N}, 18^{\circ} 58^{\prime} 28^{\prime \prime} \mathrm{E}$ & 180000 \\
D2 & Piekary Śląskie & $50^{\circ} 21^{\prime} 11^{\prime \prime} \mathrm{N}, 18^{\circ} 58^{\prime} 00^{\prime \prime} \mathrm{E}$ & 255000 \\
D3 & Piekary Śląskie & $50^{\circ} 22^{\prime} 04^{\prime \prime} \mathrm{N}, 18^{\circ} 58^{\prime} 07^{\prime \prime} \mathrm{E}$ & 62500 \\
D4 & Piekary Śląskie & $50^{\circ} 21^{\prime} 53^{\prime \prime} \mathrm{N}, 18^{\circ} 58^{\prime} 03^{\prime \prime} \mathrm{E}$ & 75000 \\
D5 & Bytom & $50^{\circ} 22^{\prime} 09^{\prime \prime} \mathrm{N}, 18^{\circ} 54^{\prime} 31^{\prime \prime} \mathrm{E}$ & 9581 \\
D6 & Radzionków & $50^{\circ} 22^{\prime} 57^{\prime \prime} \mathrm{N}, 18^{\circ} 54^{\prime} 15^{\prime \prime} \mathrm{E}$ & 110000 \\
D7 & Ruda Śląska & $50^{\circ} 15^{\prime} 58^{\prime \prime} \mathrm{N}, 18^{\circ} 52^{\prime} 11^{\prime \prime} \mathrm{E}$ & 105000 \\
D8 & Ruda Śląska & $50^{\circ} 16^{\prime} 09^{\prime \prime} \mathrm{N}, 18^{\circ} 52^{\prime} 02^{\prime \prime} \mathrm{E}$ & 50000 \\
D9 & Ruda Śląska & $50^{\circ} 16^{\prime} 42^{\prime \prime} \mathrm{N}, 18^{\circ} 51^{\prime} 51^{\prime \prime} \mathrm{E}$ & 39200 \\
D10 & Świętochłowice & $50^{\circ} 19^{\prime} 05^{\prime \prime} \mathrm{N}, 18^{\circ} 54^{\prime} 13^{\prime \prime} \mathrm{E}$ & 107600 \\
\hline
\end{tabular}

Table 1. Locations and general size of the examined dumps.

25-50\%; 4: cover $50-75 \%$ and 5: cover $75-100 \%$. Phytosociological constancy was determined [28] and cover index was calculated for each species according to the formula: the sum of average percent coverage of the species in each plot/total number of plots $\times 100 \%$. Besides epigeic lichen biota, the presence of epilithic lichens was noted or individuals were collected for detailed analysis. Total coverage of bryophytes and vascular plants was estimated. The top layers of substrate under lichen vegetation were collected to a depth of $5 \mathrm{~cm}$ and used in the chemical analyses.

The epigeic lichen biota occurring within grassland community (marked here as GSL) situated near dumps D5 and D6 was studied at three plots for comparative purposes and in order to check the general species diversity in the vicinity of the examined dumps. This community is characterized by a large proportion of the plant species from the class Festuco-Brometea. The distance between this site and D5, D6 was five kilometres. The samples of substrate from these plots were also used for chemical analyses.

The collected specimens were determined under stereomicroscope and/or light microscope according to appropriate key books (e.g. [29,30]). The lichen secondary substances were determined by means of thin layer chromatography (TLC), in solvent systems $\mathrm{C}$ and $\mathrm{G}$, in accordance with the standardised method summarised by Orange et al. [31]. All specimens are housed in KRA-L herbarium (Institute of Botany, Jagiellonian University, Kraków).

\subsection{Substrate analysis}

The substrate samples were dried and passed through a $1 \mathrm{~mm}$ sieve. Acidity $(\mathrm{pH})$ was determined by suspending the matter in $\mathrm{KCl}, \mathrm{C}$ organic content using Tiurin's method modified by Oleksynowa [32] and total $\mathrm{N}$ using
Kjeldahl's method with a Kjeltec 8100 (Foss Tecator) apparatus. Subsequently, the $\mathrm{C} / \mathrm{N}$ ratio was calculated. The total concentrations of $\mathrm{Zn}, \mathrm{Pb}$ and $\mathrm{Cd}$ were determined after the digestion of $2 \mathrm{~g} \mathrm{dw}$ in a solution of $65 \% \mathrm{HNO}_{3}$ (Merck, Suprapur) and $70 \% \mathrm{HClO}_{4}$ (Merck, Suprapur) (2:1) and were measured by atomic absorption spectrometry (AAS, Thermo Elemental Solaar). As content was made using the method of extraction of the matter in an $\mathrm{HCl}: \mathrm{HNO}_{3}$ (3:1) solution (aqua regia); afterwards, inductively coupled plasma optical emission spectrometry (ICP-OES, Optima 7300DV) was used. Certified standard solutions (MerckTitrisol, Merck-CertiPUR, Fluka-Trace CERT) were used to prepare the elemental calibration standards and quality assurance. Appropriate solutions without samples were used as reagent blanks. The analyses of elements were repeated at least three times, and the mean values were used as one observation. The values of relative standard deviation (RSD) for $\mathrm{Zn}, \mathrm{Pb}$, $\mathrm{Cd}$ and $\mathrm{As}$ were within the ranges $0.1-4.1 \%, 0.2-7.8 \%$, $0.2-5.2 \%$ and $0.4-6.7 \%$, respectively. These values showed that there was good homogeneity within a given sample.

\subsection{Statistical analysis}

A one-way analysis of variance (ANOVA) was used (after using the Shapiro-Wilk and Lilliefors tests to verify whether the data were normally distributed and Levene's test to assess the equality of variances) to compare differences in habitat parameters between particular dumps. Prior to the analysis all data were transformed into their logarithms. Next, the differences between groups were evaluated with Tukey's (HSD) test. Factor analysis, using PCA for factor extraction, was used to investigate relationships among examined habitat parameters. This technique enable reducing the number of variables and detect structure in the 
relationships between them. Prior to analysis, the data were standardised to avoid the effect of different scales of measurement. Multivariate data analysis techniques, such as indirect and direct gradient analyses, were applied to estimate the relationships between the species abundance at particular dumps and the considered habitat parameters. To account for the differing percentages of total lichen coverage in each of the surveyed plots and to show the actual relationship between species abundance proportions and habitat conditions, numerical values were transformed into a percentage scale, assuming the sum of all species abundances to be $100 \%$. A detrended correspondence analysis (DCA) was first conducted to determine whether the species matrix had a linear or a unimodal response. The length of the species abundance gradient was relatively short (i.e. 1.71), and as a consequence, the linear ordination method (RDA - redundancy analysis) was used [33]. Subsequently, a Monte Carlo permutation test was used to assess the statistical significance of the relationships between species, particular environmental factors and axes. Before the analyses, the Pearson correlation coefficients were calculated in order to reveal the correlation matrix among the examined habitat characteristics and to check if any strong correlation $(r>0.90)$ exists between variables that could potentially affect the results of multivariate analyses. Redundancy analysis was conducted on the basis of the species abundance and habitat factor results obtained from three plots per dump. Statistical calculations were performed using the STATISTICA (version 9.1; Stat-Soft Inc., http://www.statsoft.com) and CANOCO software [33].

\section{Results}

\subsection{Substrate chemical properties of the dumps} Each dump can be characterized by highly unfavorable habitat conditions and extreme heavy metal contamination. Selected chemical characteristics of the substrates obtained from the plots are presented in Table 2. One-way ANOVA $(P<0.05)$ revealed significant differences in all characteristics of the examined dumps (for F-values see Table 2). The substrates proved to be slightly acidic to alkaline and were characterized by low organic carbon and total nitrogen contents. The analyzed metal elements were recorded as a rule at much elevated concentrations even compared to the acceptable levels for post-industrial wastes (see Table 2). Figure 2 shows a plot of factor loadings of the first two factors of selected chemical properties. Three factors explained $95.0 \%$ of the total variation in the chemistry of the substrates that had developed on post-smelting dumps (Table 3). In
Factor 1 , the most important variables were $\mathrm{Zn}, \mathrm{Pb}$ and As; they comprised a positively correlated group, which represent heavy metal elements associated directly with lead and zinc smelting activities. Factor 2 includes $\mathrm{C}$ and $\mathrm{N}$, which represent soil organic matter, indirectly related to soil fertility. Whereas, Factor 3 consists only of $\mathrm{Cd}$.

\subsection{Epigeic lichen biota}

The list of epigeic lichens with their abundances, phytosociological constancies and cover indices are provided in Table 4. The most abundant was C. rei, which was frequently up to $75 \%$ coverage in the plots. Moreover, its constancy and cover index are the highest. The second most common species is $C$. cariosa, which accompanies and often coincides with $C$. rei. The other species are less frequent and have considerably lower cover indices. Nevertheless, they are usually represented by several individuals on each dump. The exception is C. cryptochlorophaea, which was recorded only on the dumps strongly contaminated with $\mathrm{Zn}$. Apart from Cladonia, representatives of two other lichen genera were present on friable slag substrate, i.e. Baeomyces rufus and Diploschistes muscorum. Both species have less than five per cent coverage in the plots. The latter species was sometimes observed as abundant but only as a parasite of $C$. rei.

Habitat factors in the vicinity of the dumps are more favourable for vegetation (Table 2). Consequently, the diversity of epigeic lichen biota at the plots of neighbouring grassland community is apparently higher than at the examined dumps. Twenty species representing ten genera were recorded: Baeomyces rufus (Huds.) Rebent., Bacidia bagliettoana (A. Massal. \& De Not.) Jatta, Cladonia cariosa (Ach.) Spreng., C. cervicornis subsp. verticillata (Hoffm.) Ahti, C. chlorophaea (Flörke ex Sommerf.) Spreng., C. fimbriata

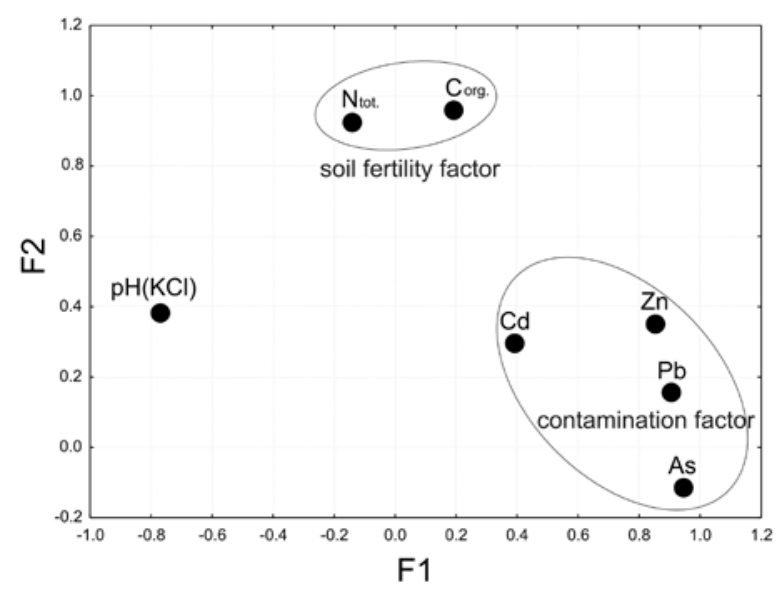

Figure 2. Scatterplot of the factor loadings (F1, F2) of substrate chemical properties for examined post-smelting dumps. 


\begin{tabular}{|c|c|c|c|c|c|c|c|c|}
\hline Dump & $\mathrm{pH}(\mathrm{KCl})$ & $\left.\mathrm{C}_{\text {org. }} . \%\right)$ & $\mathrm{N}_{\mathrm{tot}}(\%)$ & $\mathrm{C} / \mathrm{N}$ & $\underset{\left(\mathrm{mg} \mathrm{g}^{-1}\right)}{\mathrm{Zn}}$ & $\begin{array}{c}\mathrm{Pb} \\
\left(\mathrm{mg} \mathrm{g}^{-1}\right)\end{array}$ & $\begin{array}{c}\mathrm{Cd} \\
\left(\mathrm{mg} \mathrm{g}^{-1}\right)\end{array}$ & $\begin{array}{c}\text { As } \\
\left(\mathrm{mg} \mathrm{g}^{-1}\right)\end{array}$ \\
\hline D1 & $\begin{array}{l}7.45 \pm 0.30 \\
\text { D: } 2,3,4\end{array}$ & $\begin{array}{c}2.71 \pm 1.47 \\
-\end{array}$ & $\begin{array}{l}0.15 \pm 0.01 \\
\text { D: } 5,9\end{array}$ & $\begin{array}{l}17.83 \pm 9.01 \\
\text { D: } 2,4,7\end{array}$ & $\begin{array}{c}22356 \pm 1776 \\
\text { D: } 3,4,5,6,7,10\end{array}$ & $\begin{array}{c}3029 \pm 1314 \\
-\end{array}$ & $\begin{array}{l}35 \pm 21 \\
\text { D: } 5,8\end{array}$ & $\begin{array}{c}243 \pm 198 \\
-\end{array}$ \\
\hline D2 & $\begin{array}{l}7.14 \pm 0.04 \\
\text { D: } 1,3,5\end{array}$ & $\begin{array}{l}1.47 \pm 0.21 \\
\text { D: } 6,7\end{array}$ & $\begin{array}{l}0.08 \pm 0.02 \\
\text { D: } 6,8\end{array}$ & $\begin{array}{c}20.16 \pm 3.75 \\
\text { D: } 1,4,5,6,7\end{array}$ & $1446 \pm 1114$ & $\begin{array}{c}528 \pm 283 \\
-\end{array}$ & $\begin{array}{c}5 \pm 3 \\
-\end{array}$ & $\begin{array}{c}61 \pm 46 \\
-\end{array}$ \\
\hline D3 & $\begin{array}{l}7.46 \pm 0.06 \\
\text { D: } 1,2,4\end{array}$ & $\begin{array}{c}6.29 \pm 0.65 \\
\text { D: } 4,5,9,10\end{array}$ & $\begin{array}{l}0.21 \pm 0.02 \\
\text { D: } 4,5\end{array}$ & $\begin{array}{l}29.92 \pm 0.96 \\
\text { D: } 4,5,6,10\end{array}$ & $\begin{array}{c}40082 \pm 16820 \\
\text { D: } 1,4,5,6,7,8,9,10\end{array}$ & $\begin{array}{c}14797 \pm 2562 \\
\text { D: } 4,5,6,7,8,9,10\end{array}$ & $\begin{array}{l}333 \pm 17 \\
\text { D: } 4,9\end{array}$ & $\begin{array}{l}807 \pm 684 \\
\text { D: } 4\end{array}$ \\
\hline D4 & $\begin{array}{l}7.86 \pm 0.02 \\
\text { D: } 1,3\end{array}$ & $\begin{array}{l}5.84 \pm 0.23 \\
\text { D: } 3,5,8,9\end{array}$ & $\begin{array}{l}0.27 \pm 0.01 \\
\text { D: } 3,10\end{array}$ & $\begin{array}{c}21.75 \pm 1.27 \\
\mathrm{D}: 1,2,4,5,6,7\end{array}$ & $\begin{array}{c}31387 \pm 351 \\
\text { D: } 1,3,5,6,7,8,9,10\end{array}$ & $\begin{array}{l}11789 \pm 154 \\
D: 3,5,10\end{array}$ & $\begin{array}{l}362 \pm 6 \\
D: 3\end{array}$ & $\begin{array}{l}782 \pm 82 \\
\text { D: } 3,5\end{array}$ \\
\hline D5 & $\begin{array}{l}7.00 \pm 0.19 \\
\text { D: } 2,10\end{array}$ & $\begin{array}{l}5.13 \pm 0.35 \\
\text { D: } 3,4,8,9\end{array}$ & $\begin{array}{l}0.20 \pm 0.02 \\
D: 1,3,9\end{array}$ & $\begin{array}{c}26.25 \pm 0.67 \\
\text { D: } 2,3,4,6,7,10\end{array}$ & $\begin{array}{c}28529 \pm 34 \\
\text { D: } 1,3,4,6,7,9,10\end{array}$ & $\begin{array}{l}11720 \pm 258 \\
\text { D: } 3,4,10\end{array}$ & $\begin{array}{c}56 \pm 1 \\
\text { D: } 1,6,7,8 \\
9,10\end{array}$ & $\begin{array}{c}2265 \pm 118 \\
\text { D: } 4,6,8,9,10\end{array}$ \\
\hline D6 & $\begin{array}{c}6.47 \pm 0.33 \\
\text { D: } 7,8,9,10\end{array}$ & $\begin{array}{l}1.67 \pm 0.10 \\
\text { D: } 2\end{array}$ & $\begin{array}{l}0.07 \pm 0.01 \\
\text { D: } 2,7,8\end{array}$ & $\begin{array}{c}25.62 \pm 2.77 \\
\text { D: } 2,3,4,5,7,10\end{array}$ & $\begin{array}{c}47849 \pm 6349 \\
\text { D: } 1,3,4,5,7,8,9,10\end{array}$ & $\begin{array}{c}24211 \pm 947 \\
\text { D: } 3,7,8,9,10\end{array}$ & $\begin{array}{c}91 \pm 1 \\
\text { D: } 5,7,9,10\end{array}$ & $\begin{array}{c}3836 \pm 513 \\
\text { D: } 5,8,9,10\end{array}$ \\
\hline D7 & $\begin{array}{l}6.18 \pm 0.03 \\
\text { D: } 6,8,9\end{array}$ & $\begin{array}{l}1.03 \pm 0.04 \\
\text { D: } 2\end{array}$ & $\begin{array}{l}0.05 \pm 0.01 \\
\text { D: } 6\end{array}$ & $\begin{array}{c}20.48 \pm 1.81 \\
\text { D: } 1,2,4,5,6\end{array}$ & $\begin{array}{c}28360 \pm 1686 \\
\text { D: } 1,3,4,5,6,9,10\end{array}$ & $\begin{array}{c}22433 \pm 3388 \\
\text { D: } 3,6,8,9,10\end{array}$ & $\begin{array}{c}104 \pm 27 \\
\text { D: } 5,6,9,10\end{array}$ & $\begin{array}{c}12478 \pm 3306 \\
\text { D: } 8\end{array}$ \\
\hline D8 & $\begin{array}{c}6.44 \pm 0.06 \\
\text { D: } 6,7,9,10\end{array}$ & $\begin{array}{l}3.99 \pm 0.34 \\
\text { D: } 4,5\end{array}$ & $\begin{array}{l}0.08 \pm 0.00 \\
\text { D: } 2,6\end{array}$ & $\begin{array}{l}51.17 \pm 2.35 \\
\text { D: } 9\end{array}$ & $\begin{array}{c}97831 \pm 2672 \\
D: 3,4,6,9,10\end{array}$ & $\begin{array}{c}20305 \pm 361 \\
\text { D: } 3,6,7,9,10\end{array}$ & $\begin{array}{l}22 \pm 1 \\
\text { D: } 1,5\end{array}$ & $\begin{array}{c}4590 \pm 106 \\
\text { D: } 5,6,7,9,10\end{array}$ \\
\hline D9 & $\begin{array}{l}6.31 \pm 0.03 \\
\text { D: } 6,7,8\end{array}$ & $\begin{array}{l}7.42 \pm 0.34 \\
\text { D: } 3,4,5,10\end{array}$ & $\begin{array}{l}0.16 \pm 0.00 \\
\quad \text { D: } 1,5\end{array}$ & $\begin{array}{l}46.96 \pm 2.54 \\
\text { D: } 8,10\end{array}$ & $\begin{array}{c}74618 \pm 235 \\
\text { D: } 3,4,5,6,7,8,10\end{array}$ & $\begin{array}{c}21880 \pm 111 \\
\text { D: } 3,6,7,8,10\end{array}$ & $\begin{array}{c}114 \pm 2 \\
\text { D: } 3,5,6,7,10\end{array}$ & $\begin{array}{c}2465 \pm 35 \\
\text { D: } 5,6,8,10\end{array}$ \\
\hline D10 & $\begin{array}{l}6.67 \pm 0.30 \\
\text { D: } 5,6,8\end{array}$ & $\begin{array}{l}9.18 \pm 1.10 \\
\text { D: } 3,9\end{array}$ & $\begin{array}{l}0.28 \pm 0.03 \\
\text { D: } 4\end{array}$ & $\begin{array}{l}32.88 \pm 0.97 \\
\text { D: } 3,5,6,9\end{array}$ & $\begin{array}{c}54581 \pm 17869 \\
\text { D: } 1,3,4,5,6,7,8,9\end{array}$ & $\begin{array}{c}18714 \pm 6333 \\
\text { D: } 3,4,5,6,7,8,9\end{array}$ & $\begin{array}{c}82 \pm 5 \\
\text { D: } 5,6,7,9\end{array}$ & $\begin{array}{l}3357 \pm 1508 \\
\text { D: } 5,6,8,9\end{array}$ \\
\hline$F$ value & 54.68 & 86.73 & 131.83 & 22.76 & 67.48 & 141.26 & 36.45 & 53.03 \\
\hline GSL & $6.17 \pm 0.15$ & $12.23 \pm 0.59$ & $0.58 \pm 0.10$ & $21.56 \pm 3.09$ & $403.45 \pm 143.75$ & $2188.52 \pm 240.05$ & $1.4 \pm 0.60$ & $6.00 \pm 1.08$ \\
\hline & & \multicolumn{3}{|c|}{$\begin{array}{l}\text { Max acceptable level for post-industrial areas } \\
\text { in Poland' }\end{array}$} & 1000 & 600 & 15 & 60 \\
\hline & & \multicolumn{3}{|c|}{ Max concentrations for uncontaminated soils ${ }^{2}$} & 100 & 50 & 1 & 20 \\
\hline
\end{tabular}

Table 2. Chemical properties of the substrate for particular dumps $(n=3$, mean values $\pm S D)$. The dumps listed after mean values indicate that the particular dump is not significantly different from them at the $\mathrm{P}<0.05$ level according to the Tukey (HSD) test.

'Source: Regulation of the Minister of Environment (9 Sep 2002) [62]

2Source: [63]

(L.) Fr., C. furcata (Huds.) Schrad., C. conista A. Evans,

C. pocillum (Ach.) O.J. Rich., C. pyxidata (L.) Hoffm.,

C. rei Schaer., C. subulata (L.) Weber ex F.H. Wigg.,

C. symphycarpa (Flörke) Fr., Diploschistes muscorum

(Scop.) R. Sant., Leptogium biatorinum (Nyl.) Leight., Mycobilimbia tetramera (De Not.) Vitik., Ahti, Kuusinen, Lommi \& T. Ulvinen ex Hafellner \& Türk, Peltigera didactyla (With.) J.R. Laundon, Sarcosagium campestre (Fr.) Poetsch \& Schied., Stereocaulon incrustatum Flörke, Vezdea leprosa (P. James) Vezda.

\subsection{Epigeic lichen responses to habitat factors}

The relationships between lichen species distribution and habitat conditions were determined by means of RDA (Figure 3). The eigenvalues of axes 1 and 2 were 0.322 and 0.152 , respectively. This implies fairly strong gradient for the first axis and slightly weaker for the second one. The first two axes of RDA explained $57.4 \%$ of species variability $(32.2 \%$ by axis $1,25.2 \%$ by axis

\begin{tabular}{c|ccc}
\hline Parameter & Factor 1 & Factor 2 & Factor 3 \\
\hline \hline Explained variance (\%) & 51.7 & 34.7 & 8.5 \\
$\mathrm{C}_{\text {org. }}(\%)$ & 0.190 & $\mathbf{0 . 9 6 0}$ & 0.104 \\
$\mathrm{~N}_{\text {tot. }}(\%)$ & -0.146 & $\mathbf{0 . 9 2 6}$ & 0.278 \\
$\mathrm{pH}(\mathrm{KCl})$ & $\mathbf{- 0 . 7 7 0}$ & 0.385 & 0.442 \\
$\mathrm{Zn}\left(\mathrm{mg} \mathrm{g}^{-1}\right)$ & $\mathbf{0 . 8 5 0}$ & 0.352 & 0.237 \\
$\mathrm{~Pb}\left(\mathrm{mg} \mathrm{g}^{-1}\right)$ & $\mathbf{0 . 9 0 5}$ & 0.157 & 0.382 \\
$\mathrm{Cd}\left(\mathrm{mg} \mathrm{g}^{-1}\right)$ & 0.384 & 0.300 & $\mathbf{0 . 8 4 9}$ \\
As $\left(\mathrm{mg} \mathrm{g}^{-1}\right)$ & $\mathbf{0 . 9 4 3}$ & -0.113 & 0.183 \\
\hline
\end{tabular}

Table 3. Factor loadings (varimax-rotated) of substrate chemical properties determined by factor analysis for the ten studied dumps.

Loadings greater than 0.5 are shown in bold.

2). Whereas, the cumulative percentage of variance in the species-environment relationships accounted by 


\begin{tabular}{|c|c|c|c|c|c|c|c|c|c|c|c|c|}
\hline \multirow{2}{*}{ Species } & \multicolumn{10}{|c|}{ Post-smelting dumps } & \multirow{2}{*}{ Constancy } & \multirow{2}{*}{$\begin{array}{l}\text { Cover } \\
\text { index }\end{array}$} \\
\hline & D1 & $\mathrm{D} 2$ & D3 & D4 & D5 & D6 & D7 & D8 & D9 & D10 & & \\
\hline $\begin{array}{l}\text { Cladonia cariosa (Ach.) Spreng. } \\
\text { chemotype } \mathrm{I}^{1}\end{array}$ & $2 b$ & 3 & $r$ & - & - & $2 a-2 b$ & 1 & 1 & $r$ & 1 & IV & 733 \\
\hline $\begin{array}{l}\text { C. chlorophaea (Flörke ex } \\
\text { Sommerf.) Spreng. }\end{array}$ & $r$ & $r-1$ & $r$ & $r$ & $1-2 a$ & 1 & $r$ & $r$ & 1 & $r-1$ & IV & 175 \\
\hline C. cryptochlorophaea Asahina² & - & - & - & - & - & - & r & 1 & r & r & $\|$ & 54 \\
\hline C. fimbriata (L.) Fr. & 1 & 1 & r & r & $2 a$ & r & r & - & r & r & IV & 179 \\
\hline C. conista A. Evans ${ }^{3}$ & 1 & $r-1$ & $r-1$ & $r-1$ & - & $2 a$ & r & 1 & r & $r$ & IV & 200 \\
\hline $\begin{array}{l}\text { C. pyxidata agg. (including C. } \\
\text { pyxidata (L.) Hoffm. and C. } \\
\text { monomorpha Aptroot, Sipman \& } \\
\text { van Herk' } \text { S }^{4}\end{array}$ & $r$ & $r$ & $2 b$ & $2 a-2 b$ & $r$ & $r$ & 1 & $r$ & 1 & $r$ & IV & 392 \\
\hline $\begin{array}{l}\text { C. rei Schaer. } \\
\text { chemotypes I, } \|^{5}\end{array}$ & 4 & $4-5$ & 4 & 4 & $2 b$ & $3-4$ & $3-4$ & $3-4$ & $3-4$ & $3-4$ & V & 4792 \\
\hline Baeomyces rufus (Huds.) Rebent. & r & r & r & r & r & - & r & r & - & r & III & 67 \\
\hline $\begin{array}{l}\text { Diploschistes muscorum (Scop.) } \\
\text { R. Sant. }{ }^{6}\end{array}$ & $r$ & $r$ & - & - & - & $r$ & $r$ & $r$ & $r$ & - & II & 50 \\
\hline
\end{tabular}

Table 4. List of epigeic lichens on particular dumps together with their abundances (averaged on the basis of the data obtained from the plots), phytosociological constancies and cover indices.

'after Osyczka and Skubała [64];

${ }^{2}$ taxon of uncertain status; frequently treated only as the chemical variant of C. chlorophaea (see [30]);

${ }^{3}$ previously often treated only as the chemical variant of C. humilis (see [29]), currently considered as the separate species [65]; only two samples with atranorin instead of bourgeanic acid were encountered on the dump D6;

${ }^{4}$ taxon of uncertain status [30,66]; both forms/taxa were found in tight association;

5after Dolnik et al. [40]; both chemical races occurred jointly at the study plots;

${ }^{6}$ abundances are related to thalli growing directly on substrates without C. rei host.

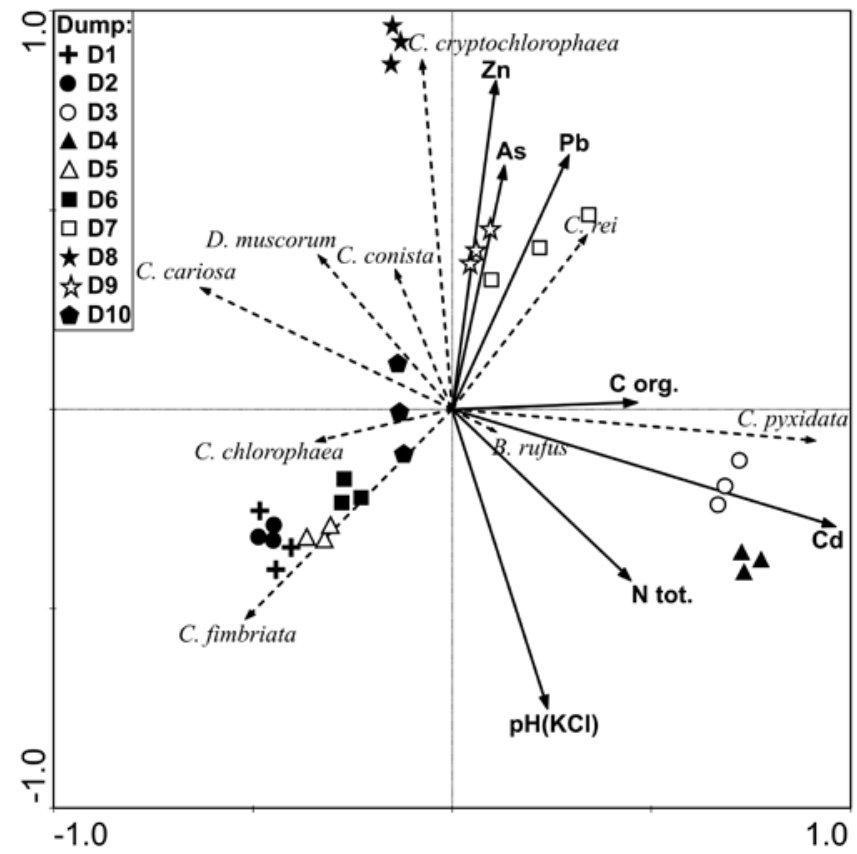

Figure 3. Redundancy analysis (RDA) ordination diagram (first two axes) for the lichen species abundance and primary substrate characteristics $\left(\mathrm{pH}, \mathrm{C}_{\mathrm{org}}, \mathrm{N}_{\mathrm{tot}}, \mathrm{Zn}, \mathrm{Pb}, \mathrm{Cd}, \mathrm{As}\right)$ of the studied plots located on post-smelting dumps (D1-D10). The cumulative percentage of variance explained by the first axis was $51.0 \%$ and the second explained 24.1\% (D1-D10 - dumps; see Table 1). 
the first two axes equalled $75.1 \%$ (51.0\% and $24.1 \%$, respectively, for the first and second axes). Speciesenvironmental correlations in RDA for the first two axes were high $\left(r_{a x 1}=0.98, r_{a x 2}=0.88\right)$. This indicates that the variables included in the analysis really captured much of the variation in the species data. The Monte Carlo permutation test showed that both the first axis and all canonical axes taken together are statistically important (F-ratio=10.43, $\quad \mathrm{P}=0.001 ; \quad$ F-ratio=5.37, $\quad \mathrm{P}=0.001$, respectively). RDA ordination distinguished the highly polluted and moderately polluted dumps (the upper side of the graph) from the less polluted ones (the lower side). According to the correlation of habitat factors with the axes, the variables determining the gradients in the RDA diagrams were, successively, $\mathrm{Cd}, \mathrm{N}_{\text {tot. }}$ and $\mathrm{C}_{\text {org. }}$ for axis 1 and $\mathrm{Zn}, \mathrm{pH}(\mathrm{KCl}), \mathrm{Pb}$ and As for axis 2 . Moving from the left to the right side of the diagram, substrate fertility and $\mathrm{Cd}$ concentration increase. The second axis determines the gradient of increasing $\mathrm{Pb}$, $\mathrm{Zn}$ and As contents and simultaneously decreasing $\mathrm{pH}$ values. The scatter of species and sites may be divided into several branches. In the upper right portion of the chart, the species resistant to high concentrations of heavy metals in the substrate are clustered. These unfavourable factors are characteristic of the most contaminated D7, D8 and D9 dumps. Cladonia rei and C. cryptochlorophaea could be included in this group. Diploschistes muscorum, C. cariosa and C. conista are associated with slightly less contaminated dumps, which are also characterized by adverse soil conditions, such as low nitrogen and organic carbon content and low $\mathrm{pH}$. These five lichens appeared to be the earliest and most effective colonisers of the dumps. Cladonia pyxidata appears to be associated mainly with dumps D3 and D4, which are characterised by high concentrations of $\mathrm{Cd}$ and relatively high organic carbon contents. The occurrence of $C$. fimbriata and $C$. chlorophaea is primarily associated with less contaminated dumps with a lower content of heavy metals in the substrate. Finally, Baeomyces rufus appears to be directed somewhat towards a higher $\mathrm{pH}$ value, organic carbon and nitrogen contents.

\subsection{Other vegetation}

Several epilithic lichens, mainly crustose, were recorded within examined plots: Candelariella aurella (Hoffm.) Zahlbr., C. vitellina (Ehrh.) Müll. Arg., Cladonia rei (directly on sinter slag), Lecanora dispersa s.lat., L. muralis(Schreb.) Rabenh., Lecidea lithophila (Ach.) Ach., Stereocaulon nanodes Tuck., S. cf. tomentosum Th. Fr., Xanthoria elegans (Link) Th. Fr. Their occurrence was restricted to small conglomerates of sintered slag and industrial rubble. The total coverage of bryophytes and vascular plants was low and usually oscillated between five and ten percent.

\section{Discussion}

\subsection{Habitat conditions at the dumps}

A slag dump is an example of an entirely artificial industrial habitat and constitutes an unfavourable environmental conditions for establishing vegetation. Dump sites are characterized by, high toxicity of the substrate, unstable and desiccated ground, immediate water flow, very high ground permeability, strong insolation and the dark colour of the substrate, which causes an intense accumulation of heat as well as daily thermal fluctuations [4]. Such disturbed habitat conditions have led to the emergence of ecosystems that are functioning under stress conditions, and new competitive systems between pioneer organisms have generated a specific species composition [34]. The total $\mathrm{N}$ content in the substrate samples was much lower than the ranges of average values given by Markert [35] for natural soils. The low total $\mathrm{N}$ content of the substrate and the simultaneous high $\mathrm{C} / \mathrm{N}$ ratio (see Table 2) creates a very unfavourable habitat for vegetation. The high $\mathrm{C} / \mathrm{N}$ ratio limits the availability of nitrate for plant growth, and the nitrogen that is available for plants is taken up by microorganisms and therefore temporarily immobilised [36]. The most alarming and rather startling results are the concentrations of the selected heavy metals (Table 2). As it can be seen, the concentrations of heavy metals are measured on a percentage scale rather than at a trace level.

\subsection{Early epigeic colonisers}

The lichens, primarily Cladonia sp. div., dominate and occur in large masses in the early stage of vegetation on the examined dumps. Undoubtedly, Cladonia rei (Figure 4) is the most abundant among all of the recorded lichens. Typically, it covers open areas and frequently forms large swards with $C$. cariosa and

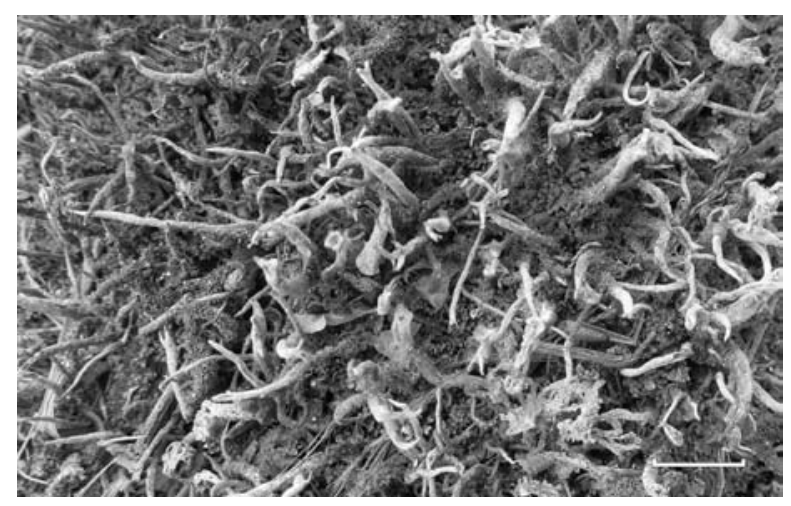

Figure 4. Sward with Cladonia rei as a dominant species in the initial stage of vegetation of post-smelting dump (D4). Scale $=2 \mathrm{~cm}$. 
representatives of the C. pyxidata-chlorophaea group as accompanying species. The occurrence of some Cladonia species within metal-enriched areas was previously documented in other parts of the world (e.g. $[13,18,37,38])$; however, the abundance, ecological value and upper limit of tolerance for metal enrichment in the environment of these species have not been resolved thus far. Apart from Cladonia, individuals of only two other epigeic lichen genera were observed on the examined dumps (see Table 4). This fact underlines the great ecological importance of Cladonia as early hardy epigeic colonisers of friable slag substrate. Moreover, Diploschistes muscorum is fairly common in some areas, but its abundance is solely correlated with $C$. rei presence, on which it is frequently parasitic. Without the host, it was only sporadically encountered (Table 4). The sparse appearance of $B$. rufus is restricted to local cavings and cracks, where the moisture and fertility conditions are more favourable. The similar aggregates of epigeic species, mostly Cladonia, appearing at the dumps indicate that these species are well-adapted for slag substrate and their occurrence is not accidental. It concerns also the dumps D1 and D2 which are somewhat less contaminated compared to the others. The mass occurrence of Cladonia species in the initial stage of succession is additionally favoured by low competition from other organisms (see also [34]).

Generally, a majority of Cladonia individuals were observed in relatively good condition and, importantly, frequently in the fertile stage. However, some abnormal forms of growth were also found and can be regarded as specific ecotypes occurring in such disturbed sites. We observed a full range of known C. rei morphotypes $[39,40]$ with a new distinct form: primary squamules conspicuous and densely packed, frequently forming compact swards, podetia robust, augmentative and decumbent, surface of podetia rough and partly densely covered by microsquamules and squamules. Atypical forms C. fimbriata were also frequently noticed. These forms can be characterised by elongated, almost subulate stalks of podetia ending with narrow and inconspicuous cups. Two morphological forms of Cladonia pyxidata, typical for the species and 'lush', were recorded on the dumps; the latter form has been sometimes treated as the separate species C. monomorpha [41,42]. Both forms/taxa were usually encountered in tightassociation; thus, we consider them jointly. Aside from morphological modifications, the colour change of thalli to a brownish or even dark brown tint was sometimes observed, especially in C. rei and C. conista. Such pigmentation is frequently explained by the increased content of heavy metals in the thalli and can also occur in other epigeic lichens $[43,44]$.

\subsection{Heavy metal-resistant lichens}

Lichens are usually considered a group of organisms that are sensitive to the presence of various pollutants in the environment, and therefore, they have been widely treated as good indicators of anthropogenic changes (e.g., [45-50]). However, there are some lichens known to have the unique ability to grow in heavily contaminated areas due to adaptive mechanisms allowing for a high tolerance to metals. Physiological processes enabling resistance to heavy metals have been observed in lichens with various ecological patterns, for example, in Xanthoria parietina (L.) Beltr., Acarospora smaragdula (Wahlenb.) A. Massal. and Diploschistes muscorum [51-53]. Many epigeic lichens, including Cladonia spp., have been reported in $\mathrm{Zn} / \mathrm{Pb} / \mathrm{Cu}$ enriched areas [38,54-58]; however, previously published records are not associated with sites as strongly affected as the examined dumps.

Our list of epigeic lichens is restricted mostly to Cladonia species. The relatively high diversity of Cladonia species combined with the deficiency of other lichen genera suggest the low sensitivity of some species of the genus to heavy metals in the environment. Although many epigeic lichen species were recorded in the vicinity of the dumps, only a few of them had colonised the examined objects and can be considered as effective pioneers. Speciesspecific differences in heavy metal susceptibility are reported here, which result in increasing abundances of certain species in strongly contaminated areas, whereas other species decrease their abundances along increasing pollution gradients. According to our results, the presence of $C$. cryptochlorophaea and $C$. $r e i$ is associated with the most contaminated dumps. Currently described specific restrained heavy metal accumulation pattern of $C$. rei reflected by a power function [23] may be one of the important attributes that facilitates its colonization of extremely contaminated dumps. Cladonia cariosa, C. conista and D. muscorum are primarily associated with less contaminated dumps and appear frequently at sites with low substrate fertility. Cladonia pyxidata grew more abundantly on dumps with a high $\mathrm{Cd}$ concentration. On the other hand, $C$. chlorophaea and C. fimbriata appear to be somewhat more sensitive to heavy metals compared to the others (Figure 3). Cuny et al. [14] also considered C. conista/ humilis, $C$. rei and $D$. muscorum to be strongly linked to heavy metal contamination, whereas $C$. chlorophaea and C. fimbriata are considered to have intermediate stress tolerance. 
4.4 Role of Cladonia in spontaneous succession Due to their pioneer nature, cryptogams, mainly lichens and bryophytes, are known as effective and rapid colonizers of bare ground not only natural sites, but also anthropogenic and artificial habitats [e.g. $8,18,20,23]$. The epigeic lichens play a fundamental role in the natural soil formation process, the consolidation of the upper substrate layer and slope stabilisation. Their thalli accumulate water droplets and atmospheric vapour, which improves local moisture conditions. Lichens provide organic matter and fixed nitrogen, and therefore, they contribute to the fertility of the substrate [59]. The colonisation and natural regeneration of the considered dumps is extremely sluggish. The process of spontaneous succession begins from a sterilised habitat and progresses towards the formation of xerothermic grasslands resembling poorly developed Festuco-Brometea or Koelerio glaucaeCorynephoretea canescentis associations $[4,60]$. Taking into consideration fruticose growth form and relatively high biomass of Cladonia, this genus proves to be the most important for the effective natural colonisation of post-smelting dumps. Although several epilithic lichens were recorded in the study plots, their occurrence was limited to small pieces of sintered slag, and thus they make a rather negligible contribution. Consequently, Cladonia swards should be considered an essential stage of succession, without which the development of stable plant cover would not be possible. This can be confirmed by earlier reclamation attempts. The support of plant cover development on such dumps by means only of 'rapid greening' methods (sowing and planting mixtures of taxa, including grasses, legumes and trees) either failed or produced poor results [4,61].

Finally, in order to better understand lichen vegetation on slag dumps and the function of particular

\section{References}

[1] Maciak F., The protection and restoration of the environment [Ochrona i rekultywacja środowiska], Szkoła Główna Gospodarstwa Wiejskiego, Warsaw, 1996 (in Polish)

[2] World Bank Group, Pollution Prevention and Abatement Handbook 1998. Toward Cleaner Production, The International Bank for Reconstruction and Development/The World Bank, Washington, 1999

[3] Puziewicz J., Zainoun K., Bril H., Primary phases in pyrometallurgical slags from a zinc-smelting waste dump, Świętochłowice, Upper Silesia, Poland, Can. Mineral., 2007, 45, 1189-1200 species, we plan to perform further studies: intracellular trace element accumulation by Cladonia thalli as a response to habitat contamination, relationship between specific $C$. rei morphotype and the molecular pattern of the species, transplantation of a small cluster with $C$. rei to bare areas of dumps in order to initiate and accelerate the process of succession.

\section{Conclusions}

Lichen species of Cladonia occur frequently and form dense swards on post-smelting dumps. In particular, $C$. rei proved to be the most tolerant and abundant epigeic species. The relatively great similarity of lichen species composition on post-smelting dumps indicates that those species are well-adapted for slag substrate and that their occurrence is not accidental. The spontaneous and rapid appearance of Cladonia lichens on slag dumps should be regarded as a positive phenomenon, crucial for the gradual and stable plant colonisation. The awareness of these facts can be helpful for planning alternative reclamation interventions. The first action we suggest to implement is protection of Cladonia swards, which could be easily achieved by restricting public access to the dumps.

\section{Acknowledgements}

We are very grateful to Magdalena Podgajny (Agricultural University, Kraków, Poland) for her organisational support in carrying out the chemical analyses of the substrate matter. The project was financially supported by the National Science Centre (Decision No. DEC2012/05/N/NZ8/00842).

[4] Skubała K., Vascular flora of sites contaminated with heavy metals on the example of two post-industrial spoil heaps connected with manufacturing of zinc and lead products in Upper Silesia, Arch. Environ. Prot., 2011, 37, 55-74

[5] Turnau K., Ryszka P., Gianinazzi-Pearson V., Van Tuinen D., Identification of arbuscular mycorrhizal fungi in soils and roots of plants colonizing zinc wastes in Southern Poland, Mycorrhiza, 2001, 10, 169-174

[6] Wierzbicka M., Rostański A., Microevolutionary changes in ecotypes of calamine waste heap vegetation near Olkusz, Poland, Acta Biol. Cracov. Bot., 2002, 44, 17-19 
[7] Skubała P., Zaleski T., Heavy metal sensitivity and bioconcentration in oribatid mites (Acari, Oribatida): Gradient study in meadow ecosystems, Sci. Total Environ., 2012, 414, 364-372

[8] Gilbert O., The lichen flora of urban wasteland, Lichenologist, 1990, 22, 87-101

[9] Kossowska M., Węgrzyn M., Lichens recorded on iron and glass in NE Poland, Polish Bot. J., 2009, 54, 123-124

[10] Paus S.M., Epigeic lichen vegetation in Northwest Germany and peripheral areas [Die Erdflechtenvegetation Nordwestdeutschlands und Einiger Randgebiete], Biblioth. Lichenol., 1997, 66, 1-222, (in German)

[11] Seaward M.R.D., Major impacts made by lichens in biodeterioration processes, Int. Biodeter. Biodegr., 1997, 40, 269-273

[12] Bačkor M., Loppi S., Interactions of lichens with heavy metals, Biol. Plantarum, 2009, 53, 214-222

[13] Purvis O.W., Halls C., A review of lichens in metalenriched environments, Lichenologist, 1996, 28, 571-601

[14] Cuny D., Denayer F.O., Foucault de B., Schumacker R., Colein P., Van Haluwyn C., Patterns of metal soil contamination and changes in terrestrial cryptogamic communities, Environ. Pollut., 2004, 129, 289-297

[15] Coppins B.J., van den Boom P.P.G., Micarea confusa a new species from zinc- and cadmiumcontaminated soils in Belgium and The Netherlands, Lichenologist, 1995, 27, 81-90

[16] Aptroot A., van den Boom P.P.G., Pyrenocollema chlorococcum, a new species with a chlorococcoid photobiont from zinc contaminated soils and wood, Cryptogamie Bryol. L., 1998, 19, 193-196

[17] Lumbsch H.T., Heibel E., Coppinsia minutissima a new genus and species in the Agyriaceae from the British Isles, Lichenologist, 1998, 30, 95-101

[18] Banásová V., Horak O., Čiamporová M., Nadubinská M., Lichtscheidl I., The vegetation of metalliferous and non-metalliferous grasslands in two former mine regions in Central Slovakia, Biologia, 2006, 61, 433-439

[19] Banásová V., Lackovičová A., Guttová A., Changes in plant species diversity around the copper plant after pollution decline, In: Tepper G.H. (Ed.), Species diversity and extinction, Nova Science Publishers, New York, 2010

[20] Palice Z., Soldán Z., Lichen and bryophyte species diversity on toxic substrates in the abandoned sedimentation basin of Chvaletice and Bukovina, In: Kováč P. (Ed.), Natural Recovery of Human-Made Deposits in Landscape (Biotic Interactions and
Ore/Ash-Slag Artificial Ecosystems), Academia, Prague, 2004

[21] Pohlová R., Changes on microsites of the moss Ceratodon purpureus and lichens Peltigera didactyla and Cladonia sp. div. in the abandoned sedimentation basin in Chvaletice, In: Kováč $P$. (Ed.), Natural Recovery of Human-Made Deposits in Landscape (Biotic Interactions and Ore/AshSlag Artificial Ecosystems), Academia, Prague, 2004

[22] Szarek-Łukaszewska G., Vegetation of reclaimed and spontaneously vegetated $\mathrm{Zn}-\mathrm{Pb}$ mine wastes in Southern Poland, Pol. J. Environ. Stud., 2009, 18, 717-733

[23] Osyczka P., Rola K., Response of the lichen Cladonia rei Schaer. to strong heavy metal contamination of the substrate, Environ. Sci. Pollut. Res., (in press), DOI: 10.1007/s11356-013-1645-6

[24] European Commission, Europe 2000+, Cooperation for European territorial development, Brussels-Luxembourg, 1994

[25] FalińskiJ.B., Maps ofanthropogenictransformations of plant cover (maps of synanthropization), In: Faliński J.B., Adamowski W., Jackowiak B. (Eds.), Synantropization of plant cover in new Polish research, Phytocoenosis 10 (NS), Suppl. Cartogr. Geobot. 9, 1998

[26] Osyczka P., Alien lichens unintentionally transported to the "Arctowski" station (South Shetlands, Antarctica), Polar Biol., 2010, 33, 10671073

[27] Bültmann H., Syntaxonomy of arctic terricolous lichen vegetation, with a survey and an example from Southeast-Greenland, Phytocoenologia, 2005, 36, 909-949

[28] Pawłowski B., The composition and structure of plant communities and methods of their research [Skład i budowa zbiorowisk roślinnych oraz metody ich badania], In: Szafer W., Zarzycki K. (Eds.), The vegetation of Poland [Szata roślinna Polski], Ed. 3, Państwowe Wydawnictwo Naukowe, Warsaw, 1977, (in Polish)

[29] Ahti T., Cladoniaceae, Flora Neotropica Monograph 78, New York Botanical Garden Press, New York, 2000

[30] James P.W., Cladonia P. Browne (1756), In: Smith C.W., Aptroot A., Coppins B.J., Fletcher A., Gilbert O.L., James P.W., et al., (Eds.), The lichens of Great Britain and Ireland, The British Lichen Society, London, 2009

[31] Orange A., James P.W., White F.J., Microchemical Methods for the Identification of Lichens, British Lichen Society, London, 2001 
[32] Komornicki T., Oleksynowa K., Tokaj J., Jakubiec J., Guide to the exercise of soil science and geology, Part II, Methods of laboratory soil analysis [Przewodnik do ćwiczeń z gleboznawstwa i geologii, Część II, Metody laboratoryjne analizy gleb], The script of the Agricultural University in Kraków, Cracow, 1991, (in Polish)

[33] ter Braak C.J.F., Šmilauer P., CANOCO Reference manual and CanoDraw for Windows User's guide. Software for Canonical Community Ordination (version 4.5), USA: Microcomputer Power, Ithaca, New York, 2002

[34] Bačkor M., Fahselt D., Physiological attributes of the lichen Cladonia pleurota in heavy metal-rich and control sites near Sudbury (Ontario, Canada), Environ. Exp. Bot., 2004, 52, 149-159

[35] Markert B., Presence and significance of naturally occurring chemical elements of the periodic system in the plant organism and consequences for future investigations on inorganic environmental chemistry in ecosystems, Vegetatio, 1992, 103, 1-30

[36] Gliński J., Chemical and physico-chemical properties of soils [Chemiczne i fizykochemiczne właściwości gleb], In: Zawadzki S. (Ed.), Soil Science [Gleboznawstwo], Państwowe Wydawnictwo Rolnicze i Leśne, Warsaw, 2009, (in Polish)

[37] Purvis O.W., Interactions of lichens with metals, Sci. Prog., 1996, 79, 283-309

[38] Rajakaruna N., Harris T.B., Clayden S., Dibble A., Olday F.S., Lichens of Callahan Mine, a copper and zinc-enriched Superfund site in Brooksville, Maine, U.S.A., Rhodora, 2011, 113, 1-31

[39] Syrek M., Kukwa M., Taxonomy of the lichen Cladonia rei and its status in Poland, Biologia, 2008, 63, 493-497

[40] Dolnik C., Beck A., Zarabaska D., Distinction of Cladonia rei and C. subulata based on molecular, chemical and morphological characteristics, Lichenologist, 2010, 42, 373-386

[41] AptrootA., Sipman H.J.M., van Herk C.M., Cladonia monomorpha, a neglected cup lichen from Europe, Lichenologist, 2001, 33, 271-283

[42] Kowalewska A., Kukwa M., Ostrowska I., Jabłońska A., Oset M., Szok J., The lichens of the Cladonia pyxidata-chlorophaea group and allied species in Poland, Herzogia, 2008, 21, 61-78

[43] Goyal R., Seaward M.R.D., Metal uptake in terricolous lichens, II. Effects on the morphology of Peltigera canina and Peltigera rufescens, New Phytol., 1982, 90, 73-84
[44] Mikhailova I.N., Populations of epiphytic lichens under stress conditions: survival strategies, Lichenologist, 2007, 39, 83-89

[45] Seaward M.R.D., Large-scale air pollution monitoring using lichens, GeoJournal, 1992, 28, 403-411

[46] Conti M.E., Cecchetti G., Biological monitoring: Lichens as bioindicators of air pollution assessment: A review, Environ. Pollut., 2001, 114, 471-492

[47] Garty J., Biomonitoring atmospheric heavy metals with lichens: theory and application, Crit. Rev. Plant. Sci., 2001, 20, 309-371

[48] Nimis P.L., Scheidegger Ch., Wolseley P.A., Monitoring with Lichens - Monitoring Lichens, NATO Science Series IV: Earth and Environmental, Kluwer Academic Publishers, Dordrecht, 2002

[49] Osyczka P., Dutkiewicz E.M., Olech M., Trace element concentrations in moss Sanionia uncinata (Hedw.) Loeske and lichens - Usnea antarctica Du Rietz and Usnea aurantiaco-atra (Jacq.) Bory collected within Antarctic research stations, Pol. J. Ecol., 2007, 55, 39-48

[50] Guttová A., Lackovičová A., Pišút I., Pišút P., Decrease in air pollution load in urban environment of Bratislava (Slovakia) inferred from accumulation of metal elements in lichens, Environ. Monit. Assess., 2011, 182, 361-373

[51] Sarret G., Manceau A., Cuny D., Van Halowyn C., Deruelle S., Scerbo R., et al., Mechanisms of lichen resistance to metalic pollution, Environ. Sci. Technol., 1998, 32, 3325-3330

[52] Purvis O.W., Williamson B.J., Bartok K., Zoltani N., Bioaccumulation of lead by the lichen Acarospora smaragdula sens. lat. from smelter emissions in the town of Zlatna, Romania, New Phytol., 2000, 147, 591-599

[53] Cuny D., Van Haluwyn C., Shirali P., Zerimech F., Jerome L., Haguenoer J.M., Cellular impact of metal trace elements in terricolous lichen Diploschistes muscorum (Scop.) R. Sant. - Identification of oxidative stress biomarker, Water Air Soil Poll., 2004, 152, 55-69

[54] Purvis O.W., The botanical interest of mine spoil heaps: The lichen story, Journal of the Russell Society, 1993, 5, 45-48

[55] Sawidis T., Chettri M.K., Zachariadis G.A., Stratis J.A., Seaward M.R.D., Heavy metal bioaccumulation in lichens from Macedonia in northern Greece, Toxicol. Environ. Chem., 1995, 50, 157-166

[56] Hajdúk J., Lisická E., Cladonia rei (lichenizované askomycéty) na stanovištiach kontaminovaných 
imisiami z Kovohút Krompachy (SV Slovensko), Bull. Slov. Bot. Spoločn. Bratislava, 1999, 21, 49-51

[57] Pawlik-Skowrońska B., Wójciak H., Skowroński T., Heavy metal accumulation, resistance and physiological status epigeic and epiphytic lichens inhabiting $\mathrm{Zn}$ and $\mathrm{Pb}$ polluted areas, Pol. J. Ecol., 2008, 56, 195-207

[58] Bielczyk U., Jędrzejczyk-Korycińska M., Kiszka J., Lichens of abandoned zinc-lead mines, Acta Mycol., 2009, 44, 139-149

[59] Brodo I., Sharnoff S.D., Sharnoff S., Lichens of North America, Yale University Press, New Haven, 2001

[60] Mańczyk A., Rostański A., Vascular flora of chosen zinc and lead smelting works spoil heaps in Ruda Śląska (Upper Silesia, Poland) [Flora naczyniowa wybranych zwałów pocynkowych miasta Ruda Śląska], Arch. Environ. Prot., 2003, 29, 107-113, (in Polish)

[61] Tokarska-Guzik B., Rostański A., Prospects and limitations of natural management of post-industrial areas [Możliwości i ograniczenia przyrodniczego zagospodarowania terenów poprzemysłowych], Natura Silesiae Superioris, 2001, Suppl. 2001, 5-18, (in Polish)

[62] Regulation of the Minister of Environment dated 9 September 2002, Official Gazette No. 165, Pos. 1359th., 2002

[63] Kabata-Pendias A., Pendias H., Trace element in soils and plants, CRC Press, Boca Raton, 2001

[64] Osyczka P., Skubała K., Chemical races of Cladonia cariosa and C. symphycarpa (lichenized Ascomycota) - a Polish case study in a worldwide context, Nova Hedwigia, 2011, 93, 363-373

[65] Pino-Bodas R., Ahti T., Stenroos S., Martín M.P., Burgaz A.R., Cladonia conista and C. humilis (Cladoniaceae) are different species, Biblioth. Lichenol., 2012, 108, 161-176

[66] Osyczka P., Yazici K., Aslan A., Note on Cladonia species (lichenized Ascomycota) from Ardahan Province (Turkey), Acta Soc. Bot. Pol., 2011, 80, 59-62 